\title{
Leaf Morphoanatomy in Hakea sericeae and H. salicifolia
}

\author{
G. Teixeira, ${ }^{*}$ A. Monteiro, ${ }^{* *}$ and C. Pepo ${ }^{* *}$ \\ * Universidade de Lisboa, Faculdade de Farmácia, Centro de Biologia Ambiental, Av. Prof. Gama \\ Pinto, 1649-003 Lisboa, Portugal \\ ** Universidade Técnica de Lisboa, Instituto Superior de Agronomia, Tapada da Ajuda, 1349-017 \\ Lisboa, Portugal
}

Hakea sericeae Schrader and H. salicifolia (Vent.) B. L. Burtt. are perennials, which belong to the Proteaceae family. Native to dry tropical zones from South Australia, they became aggressive species, particulary in damaged, dried and windy areas and are now considered invaders in some places of mainland Portugal [1], [2]. With no natural predators, the use of chemical control is the main way to manage these plants but they both show a small foliar area, therefore usually little success has been achieved [3].

In this work we use light and scanning electron microscopy to observe their leaves morphoanatomy and try to understand possible reasons for that failure. Plant material was sampled from young leaves and from 1-2 year-old shoots in natural populations of $H$. sericea and $H$. salicifolia, during 2006-2007, near Pedrogão Grande and Serra de Sintra, respectively. Plant material was prepared following the usually procedures [4].

Although their leaf morphology is quiet different, $H$. sericeae has acicular leaves and $H$. salicifolia lanceolate leaves, they present some microcharacters in common. Transverse sections of $H$. sericea show an epidermis with a thick cuticle, between 12-18 $\mu \mathrm{m}$ in young leaves and 20-30 $\mu \mathrm{m}$ in older leaves. H. salicifolia cuticle varies between 3-5 $\mu \mathrm{m}$ in young leaves and 5-18 $\mu \mathrm{m}$ in older leaves. The two taxa present sunken stomata below the epidermal surface, always overarched by cuticular ridges and a pre-stomatic chamber (Fig. 1A). Calcium oxalate crystals as raphids appear only on epidermal cells of $H$. sericea (Fig. 1B). In both species the mesophyll tissue is composed of 1-2 layers of palisade parenchyma. Inserted in between are osteosclereids, bone shaped sclereids with columnar middles and small enlargements at both ends (Fig. 1A). In H. salicifolia older leaves with $360-450 \mu \mathrm{m}$ wide, the osteosclereids can reach $100-250 \mu \mathrm{m}$ long, while in $H$. sericea they only reach 100-200 $\mu \mathrm{m}$ long, in leaves with 1820-2080 $\mu \mathrm{m}$ diameter. In $H$. sericea the vascular organization resembles to a monocot atactostele, with vascular bundles randomly scattered and a well-developed sclenchymatous bundle sheath surrounding each vein. H. salicifolia presents a more typical eudicot leaf anatomy, although palisade parenchyma is the only type seen and vessels also show a bundle sheath, less notorious when compared with those found in H. sericea.

H. sericeae and $H$. salicifolia both possess xeromorphic adaptations, less notorious in young leaves, but strongly expressed in the old leave's morphology and anatomy. These adaptations are usually correlated with dry habitats but also with the absence of certain nutrients in the soil [5-6]. The reduction of leaf area, the increased thickness of cuticle and the sunken stomata, can contribute to a reduction in the rate of water loss and may also play a key role in its chemical control by slowing the absorption of herbicides or even, preventing it. This is in accordance with studies on other plant species [7]. The presence of osteosclereids in the leaves may be explained as a requirement for support because turgor pressure can not be maintained at high levels within tissues. But sclerophilly 
has also been related with long-lived leaves, which is the case of both $H$. sericeae and $H$. salicifolia. Calcium oxalate crystal formation in plants appears to play a central role in a variety of important functions, including tissue calcium regulation, protection from herbivory, tissue support, light gathering and reflection, and metal detoxification [8].

These results elucidate us about the leaf morphoanatomy in these taxa and also help us to understand the unsuccess of their chemical control. To overcome this, attention must be paid to the plant's age and phenology, before the use of herbicides.

\section{References}

[1] http://www.uc.pt/invasoras/files/31haquea-picante.pdf (September, 07)

[2] http://www.uc.pt/invasoras/files/30haquea-folhas-salgueiro.pdf (September, 07)

[3] D. G. M. Donald and F. P. Neill. Appl. Pl. Sci. 3 (1989) 107.

[4] M. Hayat M. Principles and techniques of electron microscopy. Biological applications. 2nd ed., Edward Arnold Publ. Ltd. London, 1981.

[5] Dickison, W. C. Integrative Plant Anatomy. Harcourt Academic Press, San Diego, 2000.

[6] J.T. Martin and B.E. Juniper. The cuticles of plants. Edward Arnold Publ. Ltd. London, 1970.

[7] J.F.S. Ferreira and K.N. Ready. Weed Sci. 48 (2000) 193.

[8] P. Nakata. Plant Sci. 164 (2003) 901.

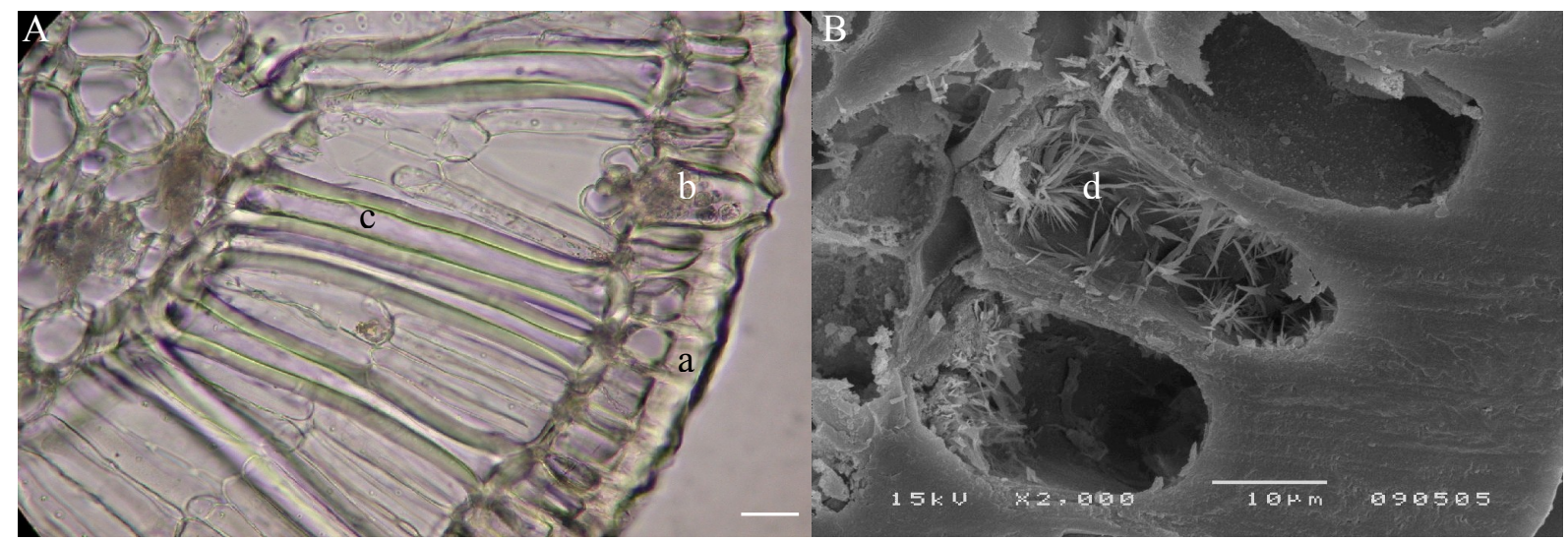

Fig. 1. H. sericeae acicular leaf cross section. A. Epidermal cells with a thick cuticle (a), sunken stomata below the epidermal surface, overarched by cuticular ridges and a pre-stomatic chamber (b) and osteosclereids (c) under epidermal cells, between the palisade parenchyma cells. Scale bar $=20$ $\mu \mathrm{m}$. B. Calcium oxalate crystals, raphids type (d), on epidermal cells. Scale bar $=10 \mu \mathrm{m}$. 